\title{
ORC2 Gene
}

National Cancer Institute

\section{Source}

National Cancer Institute. ORC2 Gene. NCI Thesaurus. Code C20380.

This gene is involved in DNA binding and the initiation of DNA replication. It also plays a role in negative control of transcription. 